\title{
Os Vandrés do sertão: Música sertaneja, ufanismo e reconstruções da memória na redemocratização
}

\author{
Sertaneja music, protests, dictatorship and politics of memory \\ Música sertaneja, protestas, dictadura y políticas de la memoria
}

Gustavo Alonso*

\begin{abstract}
Resumo: A música sertaneja foi, em grande parte, embora não somente, marcada pelo apoio ao regime ditatorial inaugurado em 1964. Assim como a quase totalidade dos gêneros musicais brasileiros, muitos artistas sertanejos apoiaram ufanistamente o regime. Este artigo visa mostrar como os músicos sertanejos reconstruíram sua relação com a memória do período ditatorial, especialmente a partir dos anos 1980, quando se engajaram no processo de redemocratização, apagando laços com o passado apologeta. Mesmo fazendo tal percurso comum a quase totalidade da sociedade brasileira, os sertanejos não conseguiram ser vistos como artistas "politizados" e permaneceram com a pecha de "adesistas" por longos anos, tema que será problematizado neste artigo.
\end{abstract}

Palavras-chave: Música sertaneja; Ditadura; Redemocratização; Resistência.

\begin{abstract}
The sertaneja music in Brazil was largely marked by the support of the dictatorial regime established in 1964. Like almost all Brazilian musical genres, many sertanejo artists supported the regime. This article aims to show how sertanejo musicians rebuilt their relationship with the regime in the 1980s, when some of them engaged in the democratization process, erasing ties with the apologist past, just like most of Brazilian citizens. However, sertanejos weren't seen as "politicized" artists and remained with the taint of "supporter of the dictatorship" for many years. The reasons why this happened are explored in this article.

Keywords: Sertaneja music; Dictatorship; Redemocratization; Resistence.

Resumen: La música sertaneja fue en gran medida, aunque no sólo, marcada por el apoyo al régimen dictatorial establecido en 1964. Al igual que casi todos los géneros musicales brasileños, muchos artistas sertanejos apoyaron vanagloriosamente al régimen. Este artículo tiene como objetivo mostrar cómo músicos sertanejos reconstruyeron su relación con la memoria del período de la dictadura, especialmente desde la década de 1980, cuando participaron en el proceso de democratización, borrando los lazos con el pasado apologista, trayectoria común a casi la totalidad de la sociedad brasileña. Sin embargo, los artistas sertanejos nunca fueron analizados como artistas "politizados" y se quedó con la mancha del "adesismo". Este articulo intenta explorar las razones de este movimiento estético y político.
\end{abstract}

Palabras clave: Música sertaneja; Dictadura; Redemocratización; Resistencia.

\footnotetext{
* Professor adjunto do Departamento de Comunicação da Universidade Federal de Pernambuco (UFPE). Historiador, mestre e doutor pela Universidade Federal Fluminense (UFF).

dados biográficos_biographic data
} 
Nesse artigo mostrar-se-á as relações ambíguas que os artistas do gênero da música sertaneja ${ }^{1}$ tiveram com a ditadura civil-militar (1964-1985) e sua relação com sua época e o meio em que viviam. Far-se-á uma análise crítica da curta bibliografia sobre o tema. Ao final, se esboçará as metamorfoses que o gênero viveu diante da redemocratização. Constataremos que a música sertaneja foi partícipe das transições brasileiras, às vezes refletindo mudanças, as vezes capitalizando transformações, e as vezes defendendo valores conservadores. Quase nunca este gênero foi passivo diante dos acontecimentos de sua época, ainda que boa parte dos analistas tenha preferido ignorar seus posicionamentos ou julgar de forma condenatória suas formações e vertentes políticas.

No livro Cowboys do asfalto: música sertaneja e modernização brasileira (ALONSO, 2015) foi demonstrado em profundidade a relação da música sertaneja com o ufanismo tão comum nos primeiros anos da ditadura e, especialmente, nos anos do chamado "milagre econômico". Aqui se focará, por causa de limites físicos, nas letras das canções sertanejas. Não se trata aqui de ignorar que a análise musical implique significados e camadas várias de possíveis pesquisas, mas sobretudo por que um dos valores principais das canções populares para seu grande público é exatamente o fato de possuir uma lírica direta, quase nunca contendo subterfúgios metafóricos ou de qualquer outra figura de linguagem, frequentemente ouvidos com distanciamento. De forma que as letras serão tomadas não como verdades absolutas, mas como vetores que nos permitem acessar, ainda que parcialmente, os valores de seu grande público. Vale rememorar como estas letras "diretas" ajudaram a construir uma época, de forma a melhor problematizarmos as metamorfoses nos artistas do sertão, assim como da sociedade brasileira diante do governo ditatorial.

\section{Um Brasil participativo}

Em diversas ocasiões artistas sertanejos respaldaram medidas e posturas levadas a cabo pelo regime ditatorial. Um dos primeiros atos dos apoiadores do golpe de 1964 foi a campanha "Doe ouro para o bem do Brasil", realizada em meados daquele ano e promovida pelos Diários Associados de Assis Chateaubriand. Ela

\footnotetext{
1 Para uma discussão acerca do gênero sertanejo e as disputas deste com a música caipira, ver: ALONSO, 2012a; 2015.
}

foi noticiada como o primeiro grande movimento dos "Legionários da Democracia" e visava estimular a sociedade a participar daquele novo governo, cujas finanças estavam combalidas desde antes do golpe. ${ }^{2}$

Empolgados com o voluntarismo e a participação popular, Moreno \& Moreninho compuseram a canção "Ouro para o bem do Brasil", lançada em junho de 1964, justamente em meio ao turbilhão de apoio à coleta do metal para apoiar a "revolução".

A sociedade se mobilizou em massa para financiar o novo governo através do ouro de alianças e jóias pessoais, assim como quantias em dinheiro. O governo golpista prometia fazer do Brasil uma grande nação, mas "precisava da ajuda do povo". Segundo a revista O Cruzeiro, pertencente ao grupo Diários Associados, a participação foi substancial em São Paulo, com doações de cerca de 100 mil pessoas.

Esse não seria o único momento de sintonia. Em vários momentos posteriores os cantores sertanejos também apoiaram ativamente a ditadura. Em 1971, Moreno \& Moreninho, a dupla conhecida como "a mais ouvida do Brasil", cantou a união nacional: "Todas as profissões unidas/ nosso mundo vai para frente/ união que faz a paz/ para um povo independente/ vamos todos com amor/ abraçar nossa bandeira/ Viva o nosso presidente!/ Viva a pátria brasileira!"

Com o povo unido, o progresso também era possível para Belmonte \& Miltinho, que em 1971 cantaram "Brasil caboclo exportação", regravada por Jacó \& Jacozinho em 1973: "Cada dia que passa o Brasil vai crescendo/ No estrangeiro agora é Brasil/ [...] / Meu amigo caboclo não perca a esperança/ sua vida tão cedo irá se modificar/ O progresso virá trazendo a bonança/ em seu rancho distante vai/ o conforto chegar."

Também em 1971 Liu \& Léo lançaram o LP Minha terra, que continha a música "Transamazônica", apologia à grande rodovia, intensamente propagandeada pelo governo como símbolo do "Brasil grande": "Meu Brasil por ti me interesso/ Mediante o progresso meu país é forte/ $[\ldots] /$ Ressaltamos nosso presidente/ que constantemente apoia o transporte/ [...] /O sentido desta minha crônica é a Transamazônica/ Muito bem traçada/ Que nasceu para nos trazer melhora/ Que grande vitória já considerada."

Em 1973 Biá \& Dino Franco gravaram "Herói da Pátria", exacerbando o elo entre o lavrador e a nação: "O caboclo com seus braços fortes/ [...] / É um herói que batalha confiante/ na grandeza de nossa nação/

\footnotetext{
2 Sem autor. "Ouro para o bem do Brasil - São Paulo repete 32".
} In: O Cruzeiro, 13/06/1964. 
Pode ver que o Brasil se agiganta/ A exemplo de um grande labor/ Parabéns a seus bons dirigentes/ Parabéns a você lavrador/ [...] / O caboclo merece respeito/ [...]/ Se preciso maneja o fuzil/ Está sempre disposto e vigilante/ Pela paz social do Brasil."

Um dos grandes apoiadores das obras e feitos da ditadura foi a dupla Tonico \& Tinoco. Em 1971 eles regravaram a canção "Esperança do Brasil", cuja gravação pioneira era de 1964, no LP lançado para comemorar seus vinte anos de carreira: "Vamos cantar este hino/ A professora ensinando/ Ama a tua escola, menino/ Que o Brasil está chamando/ [...] / Professores com carinho/ E orgulho varonil/ Preparando os pequeninos/ Esperança do Brasil."

É importante lembrar que a primeira gravação dessa canção aconteceu no ano do golpe. O tom apologético do "Brasil grande" já estava presente na obra de Tonico \& Tinoco antes de os ditadores assumirem esse tom. Ou seja, não foi o governo ditatorial que inventou o tom ufanista. Os ditadores se adaptaram a valores que já estavam latentes em diversos setores sociais. Segundo o historiador Carlos Fico, o governo ditatorial "reinventou o otimismo", trabalhando as tradições otimistas já existentes em nossa sociedade e catalisando o seu dinamismo para legitimar-se (FICO, 1997, p. 103). A música sertaneja mostra como essas tradições apologéticas já estavam presentes na sociedade, ou seja, não foram os setores populares que se subordinaram pura e simplesmente aos interesses governamentais. $\mathrm{O}$ processo foi o inverso. $\mathrm{O}$ regime se apropriou de valores e discursos já disseminados e catalisou-os em torno dos próprios interesses, projetos, obras e medidas.

Se Tonico \& Tinoco já demonstravam uma predisposição para o nacionalismo quando do golpe de 1964, durante o auge do milagre brasileiro a dupla entrou de cabeça no apoio ao Brasil grande dos ditadores. A canção "Marcha do tri”, de 1971, louvou o futebol brasileiro campeão no México no ano anterior: "Foi a maior das proezas,/ salve nosso esquadrão/ Mereceste com nobreza/ a taça do tricampeão/ Brasil, Brasil.../ Esta página da história/ simboliza tradição."

Tonico \& Tinoco eram de fato incansáveis ufanistas. Em 1972 o país viveu as comemorações pelo Sesquicentenário (150 anos) da Independência, uma data importante para o regime, que dela se utilizou para homenagear suas próprias conquistas. No auge das celebrações, o corpo de D. Pedro I foi transladado de Portugal para o mausoléu do Ipiranga, em São Paulo. Antes de ser enterrado definitivamente na capital paulista, o cortejo contendo os restos mortais do imperador vagou por todas as capitais da Federação. ${ }^{3}$ Com mais de setenta horas de vôo só no Brasil, os restos mortais de D. Pedro I foram homenageados por Tonico \& Tinoco, que gravaram "Sesquicentenário", de autoria da própria dupla: "Salve o povo brasileiro/ e seu gesto varonil/ Salve Dom Pedro I/ Libertou o meu Brasil."

No mesmo compacto a dupla lançou a canção "Bendito seja o Mobral", em homenagem ao programa do governo, o Mobral - Movimento Brasileiro de Alfabetização -, que prometia alfabetizar pessoas acima da idade escolar: "Brasil é feliz agora/ alcançou seu ideal/com a luz da nova aurora/bendito seja o Mobral/ [...] / levando um Brasil para frente."

$\mathrm{O}$ orgulho que Tonico \& Tinoco sentiam pelo Mobral é comparável ao do próprio presidente Médici, que discursou em 8 de setembro de 1970:

Considero esta iniciação um dos momentos mais felizes do meu governo, não só porque antecipo no Movimento a grande hora da alfabetização nacional, senão porque vejo no Mobral um apelo à juventude, uma trincheira contra a omissão e a fuga, uma escola de líderes e o primeiro esforço comunitário de dimensão nacional (MÉDICI, 1970, p. 115).

Outra canção que ilustra bem o tom ufanista da época é a canção "Presidente Médici", de 1973, gravada pelo sanfoneiro gaúcho Teixeirinha. Ela demonstrava que variados setores populares apoiavam o mandato do ditador, mesmo conscientes da dura e radical luta repressora levada a cabo pelo regime: "Quem é aquele gaúcho/ Que subiu pra presidência/ Dotado de inteligência/ Pra governar o país/ É bom chefe de família/ De respeito e de bondade/ Nos deu a tranquilidade/ Fez nossa pátria feliz/ [...] / Que fez um novo Brasil/ E não perseguiu ninguém// Ele nasceu no Sul/ É o presidente Médici/ Emílio Garrastazu".

É preciso ir além da condenação ou acusação que vê nos ufanistas seres "alienados" ou reacionários. Há que se compreender essa linguagem e os valores transmitidos socialmente por essas canções. Não obstante, grande parte dessa intelectualidade sempre esteve pronta a atribuir aos camponeses adjetivos que os enquadrava de ignorantes ou "alienados".

Os primeiros críticos acadêmicos da música sertaneja escreveram sobre o tema na década de 1970. José de Souza Martins e Waldenyr Caldas, trabalhando

\footnotetext{
3 Sobre a vinda dos restos mortais de D. Pedro e sua perambulação pelas capitais estaduais, ver $O$ Globo, 25/04/1972.
} 
com conceitos e métodos da Escola de Frankfurt, especialmente Theodor Adorno, tiraram conclusões duras acerca da baixa diversidade e pobreza estética da música sertaneja (MARTINS, 1975; CALDAS, 1977) Martins viu na seara sertaneja a "dissimulação" da linguagem dos dominados, contaminados pela visão dominante da temida indústria cultural. Caldas chegou a proferir que a música sertaneja seria o "barbitúrico" que doparia o proletariado consumidor de música sertaneja (p. 3-4/25).

Para João Marcos Além, pesquisador da USP, a música sertaneja se associou a indústria cultural em definitivo apenas a partir dos anos 80. Mas o veredito adorniano é basicamente o mesmo. Para o sociólogo, "com a modernização rural e a indústria cultural consolidadas e conectadas, a realidade tornou-se [...] a emergência da configuração country no Brasil", o que acarretaria em mais padronização e, logo, pobreza de variações estéticas (ALEM, 1996, p. 62). Mais recentemente o violeiro Ivan Vilela, professor da Faculdade de Música da Universidade de São Paulo, sustentou discurso parecido: "Tudo é uma escolha das gravadoras, quem decide são elas. Os produtores percebem as tendências, então os ritmos surgem praticamente de laboratórios", afirmou o professor. ${ }^{4}$

No entanto, mediante essa variada produção musical, que em verdade é só a "ponta do iceberg", não se pode dizer que os músicos populares tivessem sido castrados ou silenciados pelo regime ou pela malfadada "indústria cultural". Ao contrário, essas canções mostram como os músicos participaram intensamente do Brasil da época, emitindo opiniões, louvando medidas, legitimando posturas estatais pelas quais se sentiam atraídos. Em outros trabalhos expliquei como e por que os sertanejos se engajaram no ufanismo (ALONSO, 2015). ${ }^{5} \mathrm{O}$ apoio tem a ver

\footnotetext{
4 "Michel Teló e a marcha do sertanejo rumo ao pop", 4 de março de 2012. In: http://www.vermelho.org.br/hiphop/noticia.php?id noticia $=176860 \&$ id_secao $=11$.

5 O ufanismo é tema complexo. Ele pode ser parcial, por exemplo. Um cantor que canta uma medida do regime não necessariamente apoia in totumaquela forma de governo. $\mathrm{O}$ apoio ao regime e o diálogo com os ditadores (embora desigual) raramente foi analisado por aqueles que escreveram a história da ditadura, que preferiram polarizar o debate. Contudo, é importante compreender que consentimento e coerção aconteceram quase sempre de forma paradoxal e simultânea. Um melhor conceito foi formulado pelo historiador Rodrigo Patto Sá Motta: acomodação (MOTTA, 2014). Para além das ações repressivas, que não podem ser minimizadas, as relações durante a ditadura foram permeadas por jogos de acomodação que não se enquadram na tipologia binária resistência versus colaboração. Esta envolve conciliações pontuais que não devem ser automaticamente lidas como defesa total do regime. Apesar do aplauso ao progresso ditatorial em várias canções, os músicos sertanejos não tinham uma visão unívoca acerca do Brasil
}

com a concessão de direitos aos trabalhadores do campo operado por Médici em 1972, especialmente o ProRural e o Funrural, que garantiu aos trabalhadores rurais os mesmos direitos que haviam sido obtidos pelos trabalhadores urbanos mais de trinta anos antes, durante a ditadura Vargas.

Cabe apontar, como já foi demonstrado em outros trabalhos, que não foi apenas a música sertaneja que apoiou o regime. O historiador Paulo César de Araújo, em seu livro Eu não sou cachorro, não: Música popular cafona e ditadura militar (ARAÚJO, 2003), e o historiador Gustavo Alonso em obra intitulada Simonal: Quem não tem swing morre com a boca cheia de formiga, demonstraram a existência de várias dessas canções para além do meio sertanejo aqui exibido (ALONSO, 2011).

O que se quer mostrar aqui é que os sertanejos viveram uma metamorfose não muito diferente da vivida por grande parte da sociedade brasileira. Como já foi demonstrado por outros historiadores (REIS FILHO, 2000; ROLLEMBERG, 2006), a ditadura foi perdendo apoio aos poucos, corroída diante opiniões da sociedade que se metamorfoseava e abandonava o tom ufanista e o adesismo aos militares, ao mesmo tempo que construía uma versão sobre sua trajetória como se tivesse vivido a ditadura pura e simplesmente como um período de terror, cerceamentos e torturas. ${ }^{6}$ Obviamente, não se quer aqui negar o grau maléfico de qualquer governo ditatorial:trata-se de justamente compreender como esta percepção foi sendo forjada. Ela deve-se em parte, às rememorações acerca da época mais do que propriamente aos fatos históricos. Como já escreveu Bourdieu, a sociedade escreveu, não sem tensões e ranhuras, sua própria "ilusão biográfica" (BOURDIEU, 1996). Os sertanejos não estiveram distantes dessa reconstrução. Pelo contrário: foram agentes ativos na ideia de que a sociedade resistiu ao regime impostor.

\section{Revoltas pontuais}

Para além do ufanismo e da acomodação ao regime, não é incomum encontrar nas canções sertanejas certas discordâncias em relação à realidade que viviam. O

que ia "pra frente". Em várias canções fica claro o descontentamento com a modernização acelerada, desestabilizadora das relações camponesas tradicionais (ALONSO, 2015).

6 Para uma análise da ditadura para além da ideia de período de exceção, ver: REIS FILHO, 2000; REIS FILHO, 2004. Para uma crítica dessa memória historiográfica na música popular, ver: ALONSO, 2011. 
protesto, ainda que difuso, não era algo incomum nas canções sertanejas. Jacó \& Jacozinho gravaram a canção "Boia-fria", cujo refrão deixa claro o difícil dia a dia dos trabalhadores sazonais do interior: "Meu patrão gritou comigo/ Me chamou de boia-fria/ Não bati na cara dele/ Para não perder o dia/ Todo dia eu deito cedo/ Pra sair de madrugada/ Tomo cafezinho quente, a boia está preparada/ $\mathrm{O}$ caminhão está esperando na beirazinha da estrada/ Estou na unha do gato, estou no cabo da enxada/ É aquele vai e vem, aquela vida apertada."

Outro exemplo está na obra de Tonico \& Tinoco, que retratou a miséria do dia a dia dos trabalhadores urbanos em "Vida de operário", sem buscar saídas radicais para mudança social: "Condução atrasa, é uma amolação,/ se chego atrasado já vem o patrão/ com a cara feia me chama a atenção/ e não quer saber da minha explicação.// Se eu perco uma hora fico atrapalhado,/ não ganho domingo, não ganho feriado/ Chega o fim do mês, o meu ordenado/ não dá pra pagar onde eu comprei fiado// Ordenado é pouco, passo meus apuros/ Se não pago a Light já fico no escuro/ Quando me machuco já vou pro seguro/ e pra receber ainda é mais duro// Nossa vida é um drama, todo mundo chora,/ sempre na esperança que as coisa melhora/Vai passando o dia, vai passando as hora,/ a promessa é boa, mas como demora." Há insatisfação, mas também muita paciência.

Tião Carreiro \& Pardinho também se mostravam pouco aptos à revolta direta contra a exploração do trabalhador urbano, como na canção "Levanta, patrão", de 1975: "A fim de ganhar dinheiro, chegou na cidade grande/ Onde o progresso se expande, dinheiro corre bastante//É de cortar o coração, coitado não teve sorte/ O seu prêmio foi a morte numa firma importante./ Levanta patrão! Levanta pra ver o enterro passando/ Perdemos um companheiro no serviço trabalhando."

Apesar de denunciar os males da exploração no trabalho, efetivamente não há enfrentamento contra os latifundiários e capitães de indústria, como gostariam os mais críticos. ${ }^{7}$ Apenas se pede que o patrão respeite o defunto, mas não se protesta contra o sistema econômico capitalista que expulsa as pessoas do campo e as coloca em situação miserável nas cidades como exército de reserva da industrialização.

\footnotetext{
7 Para Waldenyr Caldas, a canção "Levanta, patrão" é "alienada" pois "instaura o conformismo". Para ele, "qualquer empregado que pretenda algo mais não deveria advertir seu patrão; agiria, simplesmente". O sociólogo diz que "Levanta, patrão", apesar de insuficientemente crítica, é a única canção que encontrou em sua pesquisa que tematizava as relações de produção na sociedade brasileira (CALDAS, 1977, p. 137-140).
}

Os autores que escreveram sobre a música sertaneja nunca viram o gênero como fonte de possíveis protestos e/ou críticas ao regime, pois essa revolta pontual não permitiria ao Brasil chegar a uma possível revolução. Seria perda de tempo buscar canções de tendências revolucionárias entre os sertanejos. No entanto, essa revolta, embora pontual, não pode ser desprezada. Cabe perguntar: será que a "revolução" é a única revolta válida?

Há várias canções sertanejas que se ocupam da temática da revolta. Esperar, no entanto, que os sertanejos falem o linguajar revolucionário seria enquadrar a música sertaneja num referencial com o qual ela pouco dialoga. Como frisa o sociólogo americano Barrington Moore Jr., "agir assim seria forçar os sentimentos e os comportamentos dos trabalhadores a se encaixarem em categorias predeterminadas, que podem guardar pouca relação com suas vidas e preocupações reais" (MOORE JR., 1987, p. 247).

Ao mostrar um tipo de revolta que não se enquadra nas esperanças acadêmicas, as músicas sertanejas apontam a possibilidade de se entender a indignação popular sob outro referencial, desvendando melhor seu sentido e por quais canais tramitam. Barrington Moore Jr. ajuda a entender que as revoltas populares são, na maioria das vezes, um anseio por se fazer escutar na sociedade. O que move as revoltas e obediência são, para Moore Jr., sensações de justiça e injustiça. Tais sensações são relativas, fluidas por excelência, e medeiam as relações das camadas populares com outros grupos sociais e o próprio Estado (idem).

Os músicos sertanejos e seu público perceberam no regime ditatorial uma abertura para se fazerem ouvidos e conseguirem direitos sociais até então negados. Em seu senso de justiça, o reconhecimento do Estado, concretizado no governo Médici, era um tratamento que os sertanejos julgavam "decente", visto que lhes conferia maior igualdade diante de outros setores da sociedade. Como diz Barrington Moroe Jr., a aceitação da ordem social não significa, pura e simplesmente, conservadorismo. A aceitação do status quo está entremeada pela ideia de que a realidade pode e deve ser modificada "no sentido de uma maior igualdade", sem, no entanto, atingir pretensões revolucionárias.

Com o senso de "justiça" satisfeito durante a ditadura, os sertanejos louvaram-na, sobretudo quando esta acenava com a possibilidade de maior igualdade, fosse entre regiões, fosse entre classes, fosse entre setores da sociedade. E especialmente pelo reconhecimento simbólico do campesinato no cenário 
político, social e econômico. Isso está longe de ser puramente conservador.

Apesar da frequente louvação aos ditadores, não havia entre os sertanejos impedimento estético de criticar os proprietários de terras, sobretudo se estes rompessem o "senso de justiça e igualdade" dos setores populares.Em "É isto que o povo quer", Tião Carreiro \& Pardinho denunciavam o interesse abusivo do patrão: "Eu arrumei um emprego do jeito que eu queria/ Pagamento todo dia, o patrão tem que aceitar/O emprego é bom de fato, assinamos um contrato/ No dia do pagamento é proibido trabalhar/ Estou gostando do emprego mas eu tenho que deixar/ O patrão não quer dar férias eu preciso descansar."

Em 1973 foi gravada "Inversão de valores", canção que mostrava que mesmo sertanejos ultrarromânticos como Milionário \& José Rico não estavam de todo acríticos à vida social. Apesar de ingênua, a música de Milionário \& José Rico é precisa ao demarcar um mundo caótico: "Queria que essa gente ambiciosa/ A sua ambição então freasse/ Num gesto de ternura e amor/ Dos que nada possuem se lembrasse/ Eu queria transformar esse mundo de dores/ Entre amores eu faria uma inversão de valores."

Os sertanejos frequentemente denunciavam a miséria de um país cujo governo ditatorial prometia a ilusão de bonança para todos. A injustiça social era visível nas cidades. A sociedade de consumo não era para todos, e isso estava presente nas canções sertanejas. Em 1974, o Trio Parada Dura gravou "Natal de um órfão", na qual deixavam clara a chaga da desigualdade social brasileira: "Às vezes fico pensando/ Como esconder a verdade/ Há pessoas que vivem sofrendo/ Outras gozam a felicidade/ O Natal de um menino órfão/ foi o que me fez pensar/ O mundo é mesmo ingrato/ quanta gente ele faz chorar."

O gaúcho Teixeirinha também ficou incomodado com as desigualdades da sociedade de consumo brasileira e compôs "Papai Noel" em 1968: "Papai Noel, lhe esperei o ano inteiro/ Só por falta do dinheiro,/ você esqueceu de mim!" Convém lembrar que essas canções foram lançadas às portas do governo Médici, época de otimismo e consumismo desenfreado. Não seriam as únicas. Em diversos momentos, os sertanejos fugiram ao tom de oba-oba generalizado.

Mais diretos, Moreno \& Moreninho protestaram em função da questão agrária. A dupla estava atenta aos acontecimentos do Brasil e do mundo em 1970. Um ano antes eles viram a chegada do homem à Lua, um dos acontecimentos mais importantes da história contemporânea. Inspirados pelos passos de Neil Armstrong em solo lunar, a dupla cantou a surreal situação de fazer reforma agrária no satélite terrestre na canção "O caipira que foi à Lua": "A Lua foi descoberta/ Amanhã eu vou pra lá/ Vou levar as ferramentas/ Pra mim poder trabalhar/ Dizem que a terra lá é boa/ Então vamos experimentar/Vou fazer reforma agrária/ Vou ver se plantando dá/ $\mathrm{Na}$ Lua vai dar de tudo/ Eu vou fazer plantação/ Vou plantar arroz e milho/ Café, batata e feijão/É lá que eu quero ver/ A fartura da nação."

A sutileza dessa canção é única. Usando o discurso entusiasmado do regime, que postulava safras recordes na história do Brasil, Moreno \& Moreninho gravaram "O caipira que foi à Lua" em plenos "anos de chumbo", em 1970, defendendo a divisão justa do solo lunar. Transformaram o discurso do regime em contraargumento, ironizando: "é lá que eu quero ver/ a fartura da nação". Ao se "mudar" para a Lua, o narradorcantor torna-se entusiasta do regime alternativo criado por ele mesmo: "Ali ninguém era dono/ Tudo de bom aconteceu/ Quando chegou a colheita/ A Lua favoreceu/ .../ Aí eu voltei pra Terra/ Deixei o solo lunar/ Contei pra minha família/ O que eu tinha feito lá/ Todos ficaram contentes/ Então nós vamos mudar/ Meus filhos ajunta tudo/ Na Lua vamos morar."

No mesmo ano em que Moreno \& Moreninho cantaram a reforma agrária da Lua, a ditadura criou o Incra, instituição governamental que deveria fazer a reforma agrária no Brasil.

Mostrando também estar antenados com o que acontecia no período do "milagre", Jacó \& Jacozinho gravaram "Manchete de jornal", em 1971. A conclusão da música demonstra uma crítica indireta ao regime que prometia pleno emprego num país que crescia a mais de 10\% ao ano: "O homem desceu na Lua/ Pelé marcou os mil/ Todo mundo foi pra rua/ Dando vivas ao Brasil/ A nova Copacabana ficou legal/ Eu li no jornal, eu li no jornal/ [...] / Na seção de astrologia/ Não demora muito tempo este mundo vai ter fim/ $\mathrm{Li}$ a página de emprego/ Não achei nenhum pra mim/ Não tava legal, rasguei o jornal."

Em 1967 Jacó \& Jacozinho regravaram "Ladrão de terra", canção originalmente lançada em 1958 por Luisinho \& Limeira que deixava claro que a revolta dos sertanejos era menos de classe e mais devido à ruptura do "senso de justiça e igualdade" que deveria guiar o Brasil: "Triste notícia chegava /Meu destino transformava/ Eu fiquei um revoltado/ Meu pai tinha falecido, na carta vinha dizendo/ As terras que ele deixou, minha mãe acabou perdendo/ Para um grande fazendeiro que abusava dos pequenos/ Meu sangue 
ferveu na veia quando eu fiquei sabendo/ Invadiu as terras minhas/ Tocaram minha mãezinha/ Pra roubar nossos terrenos/ Eu voltei pra minha terra foi com dor no coração/ Procurando meu direito eu entrei num tabelião/Quase que também caía nas unhas dos gavião/ Porque o dono do cartório protegia os embrulhão/ Me falou que o fazendeiro/ Tinha rios de dinheiro/ Pra gastar nesta questão/ Respondi no pé da letra não tenho nenhum tostão/ Meu dinheiro é dois revólveres e bala no cinturão/ Se aqui não tiver justiça para minha proteção/Vou mandar os trapaceiros pra sete palmos de chão/ Embora saia uma guerra/ Vou matar ladrão de terra/ Dentro da minha razão/ Negar terra pros caboclos/ É negar pão pros nossos filhos/ Tirar a terra dos caboclos/ É tirar o Brasil dos trilhos."

A canção "Ladrão de terra" foi regravada diversas vezes. Depois da primeira gravação, de 1958, foi relançada em 1962, 1965, 1967, 1974, 1978 e 1980 por várias duplas sertanejas. Isso demonstra a legitimidade da canção entre os músicos e público rurais. Também permite visualizar que o "senso de justiça e igualdade" dos sertanejos passou pela ditadura, ou seja, esteve presente antes, durante e depois do período ditatorial.

\section{Além do protesto}

Mesmo sem fazer protestos explícitos e "revolucionários", a música sertaneja retratou a vida das camadas miseráveis do país em várias canções. Quase todos os cantores sertanejos foram muito pobres quando jovens. E seu público ainda permanecia nessa condição. Ao cantar a realidade concreta de certas camadas sociais, os sertanejos denunciavam a condição de vida dos mais humildes cidadãos brasileiros. E, quando o fizeram, inevitavelmente esbarravam nas cores do protesto social.

Em 1972 Jacó \& Jacozinho gravaram "Pensão da rua Aurora", que conta a história de um músico que viveu a pobreza antes da fama na área de São Paulo conhecida como "Boca do Lixo", a zona paulistana do baixo meretrício: "Morei numa pensão ali na rua Aurora/ Meu Deus, Nossa Senhora, que vida que levei!/ Dormia num beliche entre pulgas e mosquitos/ [...] / Ah, ai! que vida apertada eu tinha/ Meu almoço e meu jantar era brisa com farinha/ [...] / Eu vivia num dilema com a barriga roncando/ De tanto andar a pé até esfolei meu pé..."

Até Chitãozinho \& Xororó, tradicionais cantores de amores abandonados, emprestaram as vozes para, em 1979, cantar a sofrida vida de uma prostituta em
"Ninguém quis dormir": "Pra ganhar o pão, entrega seu corpo/ É a profissão que a vida lhe deu/ Porque certo dia amou de verdade/ Alguém que a enganou e assim se perdeu/A realidade saiu pelo mundo/ Deixou o seu lar e não teve perdão/ Mulher, o seu corpo é tão conhecido/ Mas ninguém conhece o seu coração."

O drama social da prostituição foi cantado muitas vezes pelos sertanejos. Um dos maiores clássicos do repertório de João Mineiro \& Marciano, a canção "A bailarina" conta a história de uma menina que sonhava viver da dança mas acabou se prostituindo. A denúncia desse drama muito comum no Brasil é cantada com todas as letras: "Ela era quase criança,/ Nos sonhos bons de menina/ Queria ser bem famosa, queria ser bailarina/ E despediu-se bem nova, contra a vontade dos pais/ $E$ foi tentar a carreira, não retornou nunca mais/ Para contar sua história não preciso tanto/ Ela foi sempre enganada e as coisas mudaram/ No fim perdeu a carreira,/ Tornou-se na vida uma famosa amante que todos amaram/ A bailarina venceu e tem fama demais/ Apenas é diferente o caminho porém/ Ela não dança no palco, recebe um por vez/ Naquele quarto bonito, a platéia vem/ [...] / Abraça o fã que lhe paga, a fama foi ilusão."

O Trio Parada Dura também foi tocado pelo tema da prostituição. Em "Juramento", o cantor Barrerito jurava amor a uma prostituta, a despeito do preconceito por sua condição social: "Entre os que vêm comprar seus carinhos/ eu também me encontro apaixonadamente/ Mas uma mulher que é de todos os homens/ Não consegue mesmo ser de um somente/ [...] / Porém se existem as damas da noite/ Eu não ignoro pois pensando bem/ Nenhuma tem culpa da sorte mesquinha/ por ser entre as flores a erva daninha/ E acima de tudo ser gente também." O drama da desigualdade social e o poder do dinheiro foram outros problemas denunciados pelos sertanejos. Em "O dinheiro compra tudo", Chitãozinho \& Xororó tematizaram a vida de uma jovem vendida para se casar: "Desde os tempos de Cristo bendito/ que o ouro maldito supera o amor/É por isso que o pai de família/ vendeu sua filha e não lhe deu valor/ Eu não culpo a moça, coitada!/ pois foi obrigada com outro se casar/ Eu condeno o homem de estudos/ que põe o dinheiro acima de tudo/ e cria uma filha para negociar."

Nem sempre as canções de denúncia das condições dos mais humildes eram pessimistas e tristes. Houve casos em que os sertanejos buscaram apontar as desigualdades sociais e rompê-las de forma otimista. Um dos maiores clássicos do Trio Parada Dura é "O doutor e a empregada", canção em que as barreiras de classe são rompidas em nome do amor: "Mamãe eu 
estou gostando da empregada/ E cada dia que passa eu gosto mais/ [...] / A sua simplicidade me conquistou/ Eu sinto que ela sente o mesmo por mim/ Não importa o que ela é nem o que eu sou/ Não quero que nosso amor venha a ter fim//Pode me bater, pode me pisar,/ Pode me xingar, pode me humilhar,/ Pode me chamar... de doutorzinho meia-tigela/ pode fazer tudo que eu não me zango com a senhora/ mas se mandar a empregada embora/ eu vou com ela/ [...] / O diploma que eu tenho só tem valor/ se ela for minha esposa e sua nora/ Eu tenho na empregada um grande amor/ sem ela eu vou jogar meu diploma fora."

Em "Homem de cor", de 1981, o Trio Parada Dura questiona o racismo nas relações amorosas, explanando abertamente algo sobre o qual frequentemente se cala no Brasil: "Enquanto estava mendigando não viu que eu era um homem de cor/ Agora quem já tem de tudo diz que não mereço/ Diz que seu amor já subiu de preço/ Que é muito pouco tudo que lhe dou/ [...] / Mesmo assim a nossa união podia dar certo/ Se não existisse em você o orgulho/ Que a cor da pele é que faz o homem/ Mas você já esqueceu/ Que o sangue que corre nas veias de um negro/ Matou sua fome e lhe deu sossego/ É com este sangue que assina seu nome."

As canções sertanejas refletiam a vida de milhões de ouvintes, revelando a exploração cotidiana e as desigualdades sociais. O historiador Paulo César de Araújo constatou essa revolta pontual em seu livro Eu não sou cachorro, não: música popular cafona e ditadura militar. Araújo mostrou que os músicos da geração cafona dos anos 1970 tematizaram o cotidiano sofrido dos seus ouvintes. Narrando a vida dos explorados e miseráveis, artistas como Odair José, Evaldo Braga, Waldick Soriano cantaram a realidade de seu público. Há que se melhor compreender essa postura, como diz Paulo Cesar de Araújo:

Não se quer dizer que haja nos discos desses artistas refutação ou combate social à ordem social, mas sim mensagens dotadas de uma lógica que se transforma em atos de resistência, considerandose as dificuldades de recusar ou mesmo questionar o projeto político-social conduzido pelos militares no período do AI-5. Nunca é demais lembrar que aquele foi um período de ênfase no patriotismo e de acentuada crença no mito da união de todas as classes em prol de um objetivo comum. Entretanto, ao descrever a dura realidade dos pobres, dos negros, dos meninos de rua, das empregadas domésticas, dos imigrantes nordestinos, dos camponeses sem terra, dos analfabetos, dos homossexuais e das prostitutas, os artistas 'cafonas' revelavam de uma maneira simples e clara - e para um grande público - aquilo que os ideólogos do regime procuravam dissimular ou esconder; ou seja, as desgraças do cotidiano e o caráter conflitivo, autoritário e excludente da sociedade brasileira (ARAÚJO, 2003, p. 333-334).

$\mathrm{O}$ mesmo se pode pensar em relação à música sertaneja, de forma que é preciso analisá-la para além do ufanismo. Apesar do aplauso ao progresso ditatorial em várias canções, os músicos sertanejos não tinham uma visão unívoca acerca do Brasil que ia "pra frente". Em várias canções fica claro o descontentamento com a modernização acelerada, desestabilizadora das relações camponesas tradicionais.

Em 1971 Pedro Bento \& Zé da Estrada gravaram "Mágoa de boiadeiro", um lamento diante do desaparecimento dessa profissão: "Antigamente nem em sonho existiam/ tantas pontes sobre os rios nem asfalto nas estradas/ A gente usava quatro ou cinco sinueiros/ pra trazer o pantaneiro no rodeio da boiada/ Mas hoje em dia tudo é muito diferente/ com progresso nossa gente nem sequer faz uma ideia/ Que entre outros fui peão de boiadeiro/ por esse chão brasileiro os heróis da epopeia."

Também em 1967 Belmonte \& Amaraí gravaram o grande clássico "Saudade de minha terra", uma crítica à modernidade acelerada prometida pelo desenvolvimentismo ditatorial: "De que me adianta viver na cidade/ Se a felicidade não me acompanhar/ Adeus, paulistinha do meu coração/ Lá pro meu sertão, eu quero voltar/Ver a madrugada, quando a passarada/ Fazendo alvorada, começa a cantar/ Com satisfação, arreio o burrão/ Cortando estradão, saio a galopar/ E vou escutando o gado berrando/ Sabiá cantando no jequitibá."

"Saudade da minha terra" foi regravada inúmeras vezes. Cantaram-na Sérgio Reis, Milionário \& José Rico, Chitãozinho \& Xororó, Leonardo, Michel Teló e Daniel, entre muitos outros. A cidade era com frequência vista como sinônimo de solidão, perda de valores e infelicidade. Em 1973 Jacó \& Jacozinho gravaram "Gente da minha terra", canção que havia sido gravada no ano anterior por Belmonte \& Amaraí: "Eu gosto da vida também da cidade/ E sei que existe a felicidade/ Mas deve ser filha do interior."

A dupla Jacó \& Jacozinho cantou a fuga da cidade caótica e a volta ao campo em vários LPs. Em 1969 gravaram "Cavalo enxuto", um balanço crítico do progresso do Brasil: "O progresso é coisa boa, reconheço e não discuto/ Mas aqui no meu sertão, meu 
cavalo é absoluto/ Foi Deus e a natureza que criou este produto/ Esta vitória foi minha e do meu cavalo enxuto." Em 1975 gravaram "Filho de pobre", na qual entoaram a tristeza de morar na cidade grande longe do sertão: "Mamãe, eu saí de casa/ Por um futuro melhor/ Vivendo aqui tão distante/ já vi que tudo é pior/.../ Eu saí atrás dos cobres/ Me sinto muito mais pobre/ Vivendo aqui tão só." No mesmo disco a dupla gravou "Longe do asfalto", louvando a pureza da vida natural do campo: "Onde eu estou morando o progresso não chegou/ a minha tranquilidade ainda não acabou/ $\mathrm{Na}$ frente da minha casa/ o asfalto não passou/ [...] / Vivo longe do asfalto/ bem no alto da colina/ a minha televisão é a beleza das campinas/ O meu carro é de boi que canta e não desafina/ prefiro o cheiro do gado do que o da gasolina."

Um ano depois, em 1976, Jacó \& Jacozinho lançaram "Amigo lavrador", clamando pelo fim do êxodo rural que alimentava as cidades com exército de reserva de trabalhadores baratos, promotor do desenvolvimento capitalista ditatorial: "Meu amigo lavrador/ Aqui vai o meu pedido/ Não abandone a lavoura/ Nem o meu sertão querido/ Aqui na cidade grande/ Tem gente desiludida/ Abandonar a lavoura/ estão muito arrependidos."

Apesar das várias canções sobre o campo, e até algumas combativas ao status quo desenvolvimentista, os sertanejos raramente são lembrados por esse tipo de produção. Em 2006 a cientista política Heloisa Starling se "esqueceu" dessas músicas quando escreveu um artigo intitulado "Canto do povo de um lugar". Tratava-se de um artigo acerca das músicas sobre a terra no cancioneiro urbano (STARLING, 2006). Foram lembrados Chico Buarque, Caetano Veloso, Carlos Lyra, Noel Rosa, João Gilberto, Tom Jobim, Caymmi, Milton Nascimento, Paulo Vanzolini, Catulo da Paixão Cearense, Pixinguinha, Gilberto Gil, Rita Lee... Ou seja, todos aqueles artistas identificados à MPB. Mas nada foi dito sobre Milionário \& José Rico, Leo Canhoto \& Robertinho, Trio Parada Dura e Jacó \& Jacozinho, ouvidos por milhões de trabalhadores do campo, mas também nas periferias das cidades.

$\mathrm{O}$ mesmo erro cometeram os professores doutores Roberto José Moreira e Luiz Flávio de Carvalho Costa, que organizaram Mundo rural e cultura, lançado em 2002. Trata-se de um livro que contém artigos de renomados pesquisadores da questão cultural no campo brasileiro. Nenhum artigo foi escrito sobre a música sertaneja, e apenas um tratava da música popular: o foco era novamente como a MPB tematizou a resistência no campo (MOREIRA \& COSTA, 2002). A resistência sertaneja nunca foi abordada até hoje. Como se sabe, o esquecimento dos sertanejos e a lembrança da MPB não eram fruto do acaso: trata-se de omissão comum da memória coletiva brasileira.

\section{Os Vandrés do sertão}

Como que para provar que em toda regra há exceção, houve sertanejos que adotaram a temática revolucionária em suas músicas. É o caso da dupla Duduca \& Dalvan, que estava atenta ao cenário político brasileiro do início dos anos 1980 e criou canções de protesto contundentes.

José Trindade, o Duduca, goiano de Anápolis, conheceu José Gomes de Almeida, o Dalvan, em 1975. Começaram a fazer turnês dois anos depois e em 1978 lançaram seu primeiro disco. Empolgados com a redemocratização, a dupla passou a gravar canções políticas nos anos 1980 .

A primeira foi "Anistia de amor", gravada no LP homônimo de 1983, que fazia uma releitura da discussão da anistia política para a relação amorosa: "Vou lhe dar uma anistia de amor pra ver se agora podemos nos entender/ Vou abrir novamente a minha porta e dar um cantinho da cama a você."

Vivia-se a redemocratização após longos anos de ditadura, e Duduca \& Dalvan surfavam na onda. A transformação de um tema político, a anistia, em tema amoroso poderia ser entendida como deturpação pelos mais críticos. Não foi o que se viu nos discos seguintes. Ao invés de suavizar os questionamentos políticos, Duduca \& Dalvan incrementaram os protestos.

No disco seguinte, o LP Espinheira, de 1984, a dupla regravou o clássico "Para não dizer que não falei de flores", de Geraldo Vandré, cujo refrão de protesto é um clássico da MPB: "Vem, vamos embora que esperar não é saber/ Quem sabe faz a hora, não espera acontecer."

Duduca \& Dalvan não se contentaram com regravações. Engajado nos ares libertários do fim da ditadura, Dalvan compôs a canção que deu título ao disco, o protesto "Espinheira": "Eta espinheira danada/ Que pobre atravessa pra sobreviver/Vive com a carga nas costas/E as dores que sente não pode dizer// Sonha com as belas promessas/ De gente importante que tem ao redor/ Quando entrar o fulano/ Sair o sicrano será bem melhor/ Mas entra ano e sai ano/ E o tal de fulano ainda é pior/ Esse é meu cotidiano/ Mais eu não me dano pois Deus é maior". No LP de 1986, veio outra bomba: "Massa falida". A música, uma balada com 
trompetes, cordas, bateria e violões, foi lançada em meio aos acontecimentos do fim da ditadura.

Em 15 de janeiro de 1985 Tancredo Neves havia sido eleito presidente pelo Colégio Eleitoral através do voto indireto, mas não tomou posse em 15 de março, como previsto. Adoentado, foi internado.Morreria em 21 de abril, 39 dias depois. Em seu lugar tomou posse o vice, José Sarney, ativo civil apoiador da ditadura. Diante desse cenário, Duduca \& Dalvan viram-se desiludidos com o jogo político brasileiro e defenderam a utopia revolucionária de "Massa falida": "Eu confesso já estou cansado de ser enganado com tanto cinismo/ Não sou parte integrante do crime e o próprio regime nos leva ao abismo./ Se alcançamos as margens do incerto foram os decretos da incompetência/ Falam tanto sem nada de novo e levam o povo à grande falência!// Não aborte os seus ideais/ No ventre da covardia/ Vá a à luta empunhando a verdade/ Que a liberdade não é utopia!// Os camuflados e samaritanos nos estão levando a à fatalidade,/ Ignorando o holocausto da fome, tirando do homem a prioridade/ $\mathrm{O}$ operário do lucro expoente e a parte excedente não the é revertida,/ Se aderirmos os jogos políticos seremos síndicos da massa falida!/ Não aborte os seus ideais...".

Na contracapa do LP Massa falida a dupla aparecia vestida de operários da construção civil, denotando a ligação com seu público. O disco chegou a vender 500 mil cópias e foi o auge da dupla, que ficou conhecida como "os leões da música sertaneja". ${ }^{8}$ Foi o último trabalho da dupla: naquele mesmo ano Duduca morreu.

Sem o companheiro, Dalvan, na época com 35 anos, seguiu a linha da crítica social em suas canções. O cantor, que também era compositor de seus principais protestos, é um caso especial da música sertaneja. É o único sertanejo das gerações dos anos 1970 e 1980 que frequentou os bancos de uma universidade.

Filho de cearenses, nascido em 1951 numa pequena cidade do interior do Paraná chamada Lobato, perto de Maringá, o cantor só foi registrado em Planaltina. $\mathrm{Na}$ adolescência Dalvan foi criado em Paranavaí, também no Paraná. Aos 18 anos serviu o Exército, onde ficou até 1973. Entrou então na Polícia Civil, onde ficou até formar a dupla com Dalvan. Foi nesse período que cursou dois anos de Direito e trancou o curso. A duras penas, depois de famoso, conseguiu terminar a faculdade. Dalvan tinha medo da fama momentânea

8 Sem autor. "A toada engajada". In: Revista Veja, 17/08/1988, p. $116-117$. e se preparava para ser delegado caso a vida artística chegasse ao fim. ${ }^{9}$

Mas não foi isso que aconteceu. Dalvan continuou gravando protestos em carreira solo, e cada vez mais radicalizando o discurso. A música "Novo rumo", de sua autoria, puxou o LP homônimo de 1986: "Se a fome está em sua porta/ Não se entregue a uma esperança morta/ Erga a cabeça para se manter/ Esse desacerto é da sociedade/ Vá pedir comida às autoridades,/ Pois só eles detêm o poder."

Em 1987 Dalvan prosseguiu incansável na rebeldia. "Trem da vida (Estação da Luz)" é outra canção sobre a realidade de seus ouvintes: "É madrugada ainda não raiou o dia/ Mas quem trabalha e mora longe está de pé/ Jeito apressado, ainda meio sonolento/ [...] / Lá vem o trem, o trem já vai/ Levando o povo cada um com sua cruz/ Lá vem o trem, o trem já vai/ Cheio de gente rumo à Estação da Luz."

Apesar de contundentes, dos protestos de Dalvan nenhum foi tão enfático quanto "Quero terra", um petardo pela reforma agrária lançada em pleno ano da Constituinte de 1988: "Igual a tantos outros eu também sofro bastante/ Venho vindo de outras terras, eu aqui sou imigrante/ Com a mulher e filhos vamos levando a vida/ Esperando encontrar nossa terra prometida// Quero terra para trabalhar/ Quero terra para plantar/ [...] / Quero ter um lugarzinho e semear muitas sementes/ Para acabar com a fome que maltrata tanta gente."

Em entrevistas para o lançamento de "Quero terra", em 1988, Dalvan não fugia da raia e aproveitava os microfones para protestar: "Acho que quem tem uma monstruosidade de terra deve deixá-la para quem quer trabalhar", dizia o cantor. "Se eu quisesse fazer sucesso, iria gravar músicas românticas. Quero, com meus protestos, alertar as autoridades". ${ }^{10}$

Houve uma personagem importante da sociedade brasileira que foi tocada pelas canções de protesto de Dalvan: tratava-se do então sindicalista e fundador do PT Luiz Inácio Lula da Silva. O futuro presidente Lula ouvia as canções de Dalvan na boca dos metalúrgicos da periferia de São Paulo na década de 1980.

O primeiro encontro entre Lula e Dalvan aconteceu em 2006, em Santo Amaro, zona sul de São Paulo. Lula fazia campanha pela reeleição para presidente quando foi interceptado por Dalvan, que queria cantar para ele.

\footnotetext{
9 Para os dados biográficos, Programa No Rancho da Prosa, com Duduca e Dalvan, postado no YouTube em 25/01/2013: http:/ www.youtube.com/watch?v=ygNLBOyzYiU.

${ }^{10}$ Sem autor. "A toada engajada". In: Revista Veja, 17/08/1988, p. 116-117.
} 
Imediatamente o então presidente lembrou-se do cantor e disse, empolgado:

Eu ganhei minhas eleições de 1986 para deputado colocando esta música pra tocar na porta de fábrica sem parar [desde] às 5 horas da manhã... Era "Espinheira"... Não precisava gastar um tostão. Era colocar a música e falar "o Lula tá aqui pra falar com vocês...". Você não me conhecia e não podia pedir direitos autorais... [risos, Lula abraça Dalvan efusivamente] (DUDUCA..., 2012). ${ }^{11}$

Apesar das canções contundentes, Dalvan nunca foi reconhecido como cantor de protesto pela crítica musical. E não foi o único a protestar e a ser esquecido.

A redemocratização seduziu muitos sertanejos. Diferentemente da luta armada nos anos 1960 e 1970, a campanha das Diretas Já, na primeira metade dos anos 1980, conseguiu dialogar com as massas brasileiras. Os sertanejos, tocados pela crise que vivia a sociedade brasileira e seduzidos pelo discurso simpático da redemocratização, mudaram de lado e passaram a criticar a ditadura. Tornaram-se democratas de última hora.

Um dos maiores entusiastas da redemocratização foi o sanfoneiro gaúcho Teixeirinha. $\mathrm{Na}$ década anterior Teixeirinha havia sido um ufanista em tempo integral da ditadura, chegando até a fazer canção em homenagem ao presidente Médici. Nos anos 1980 passou a criticar os ditadores. Em entrevista ao jornal Folha da Tarde em 1984, Teixeirinha defendeu o voto direto: "O povo deve ter o direito de escolher, pois se ele errar nós podemos ser responsabilizados, caso contrário, não fomos nós que escolhemos [...] Não quero saber de partido, quero um homem que trabalhe, que honre o voto dado pelo povo. [...] Cobrar impostos não é trabalhar." 12

Teixeirinha morreu em 1985, mas Mary Teresinha, sua mulher por 22 anos, continuou lançando discos, como fizera ao lado do marido até então. Em 1987 ela gravou a canção "Diretas Já", que pedia o voto direto para presidente: "O povo já está cansado de ser enganado/ Reformas, mudanças, cruzeiro e cruzado,/ tudo é mentira, tudo é ilusão/ [...] /Senhores, tenham

\footnotetext{
${ }^{11}$ Encontro sem data precisa. Referência confirmada em conversa informal com Dalvan via telefone em 26/07/2012. Vídeo postado com o título de "Duduca \& Dalvan com o presidente Lula", publicado no YouTube originalmente em 14/06/2007. O vídeo desapareceu e eu mesmo o republiquei em 26/04/2016: https:// www.youtube.com/watch? $v=q$ GiEyQZLeQQ.

${ }^{12}$ Sem autor. "Teixeirinha quer eleições diretas", Folha da Tarde, 17/01/1984. Apud: COUGO JR., 2010, p. 139.
}

consciência de suas derrotas/ Entendam que todos os planos falharam/ Não há mais saída se continuar/ Já basta, parem por aqui/ Nada mais nos serve/ Deixa o povo escolha quem deve/ Este continente que irá governar/ [...] /Diretas Já, chega de traição/ Melhores salários para o operário/ Mais estudo e pão!” Na época Mary Teresinha tornara-se partidária do PDT e sonhava com Leonel Brizola na Presidência da República. ${ }^{13}$

É interessante notar que parte da sociedade brasileira fez esse mesmo percurso durante os anos 1980. Na virada da década, quase todos preferiram mudar de lado e esquecer o apoio que havia sustentado o regime. $\mathrm{E}$ foi nesse contexto que vieram à tona canções críticas em profusão contra o regime.

Em 1983, no fim do governo Figueiredo, Tião Carreiro \& Pardinho cantaram "A coisa tá feia": "Quem dava caixinha alta, já está cortando a gorjeta/ Já não ganha mais esmola nem quem anda de muleta/ Faz mudança na carroça quem fazia na carreta/ [...] / quem mamava no governo agora secou a teta/ A coisa tá feia, a coisa tá preta."

Com o fracasso do plano econômico de Sarney, o Plano Cruzado, Tião Carreiro \& Pardinho voltaram a protestar com a canção "Osso duro de roer": "Osso duro de roer/É o Brasil da qualidade/ É doído a gente ver/ A cruel desigualdade/ O pobre fica mais pobre, $\mathrm{O}$ rico enriquece mais,/ Tubarões e agiotas/ Aumentam seus capitais/ Os tais colarinhos brancos/ Da cadeia vive ausente." Desiludido, Tião Carreiro achava que protesto musical não gerava resultados: "É pura perda de tempo, há anos fazemos a mesma coisa e até agora não adiantou nada." 14

Nesse mesmo ano de 1987 Mary Teresinha e a dupla Chico Rey \& Paraná gravaram separadamente "A grande esperança", canção que demarca a luta de classes no campo brasileiro. Diante da promulgação da Constituição, os sertanejos faziam pressão pela divisão do campo entre os pequenos produtores e denunciavam a vida opressora do capitalismo brasileiro: "A classe roceira e a classe operária/ Ansiosas esperam a reforma agrária/ Sabendo que ela dará solução/ Para situação que está precária/ Saindo o projeto no chão brasileiro/ De cada roceiro ganhar sua área/ Sei que em miséria ninguém viveria/ E a produção já aumentaria/ Quinhentos por cento até na pecuária!/ [...] / O ricaço que vive folgado/ Acha que o projeto, se for assinado,/ Estará ferindo a Constituição/ [...] / Que eles não deixem o capitalismo/ Levar ao abismo a nossa nação,/

\footnotetext{
${ }^{13}$ Sem autor. "A toada engajada". In: Revista Veja, 17/08/1988, p. 116-117.

${ }^{14}$ Idem.
} 
A desigualdade aqui é tamanha/ Enquanto o ricaço não sabe o que ganha/ $O$ pobre do pobre vive de ilusão!”

Quando gravaram "A grande esperança”, Chico Rey \& Paraná tiveram problemas com os fazendeiros que com frequência contratavam seus shows: "Achamos que a reforma agrária era um tema da moda, muito discutido na Constituinte", explicou Chico Rey. "A música fez sucesso entre os agricultores, mas os latifundiários não gostaram muito", completou Paraná, que garantiu ter sofrido ameaças em regiões controladas pela União Democrática Ruralista (UDR) - organização dos proprietários que lutaram na Constituinte de 1988 contra qualquer reformismo no campo. A solução encontrada pela dupla para serenar os ânimos foi a eventual autocensura. "Decidimos nunca mais cantar 'A grande esperança' em exposições de gado, para não criar problemas", afirmaram.

Chico Rey se dizia apartidário e justificava suas canções de protesto graças à boa receptividade do público: "Quanto mais a situação do país se agrava, mais o mercado para a música sertaneja com críticas sociais se amplia", acreditava. ${ }^{15}$

\section{Um sertão a descobrir}

$\mathrm{Na}$ década de 1980 o protesto se tornou algo vendável e, em determinada medida, até desejável. Junto com a sociedade brasileira, os sertanejos faziam uma metamorfose política. Ambos, sociedade e músicos, decidiram esquecer o apoio dado aos ditadores e passaram a aceitar e desejar a democracia. Por que tanto o apoio ufanista quanto a metamorfose sertaneja nunca foram lembrados pela bibliografia?

Penso que em grande parte da bibliografia impera, na maior parte das vezes implicitamente, aquilo que Roberto Schwarz descreveu em 1970 como "hegemonia cultural da esquerda" (SCHWARZ, 1970). ${ }^{16}$ Trata-se da impressão de que, devido a grande contestação dos "anos rebeldes", tão largamente descrita em livros e na mídia após a redemocratização, "a esquerda", usada no singular por Schwarz, hegemonizaria a produção cultural durante a ditadura. Nesse sentido, quando se fala de "resistência", pensa-se logo na MPB como seu principal constructo. Como sabemos, no entanto,

\footnotetext{
${ }^{15}$ Sem autor. "A toada engajada". In: Veja, 17/08/1988, p. 116-117. ${ }^{16}$ O próprio Schwarz chamou a "Marcha da Família, com Deus pela Liberdade" de apoio ao golpe 1964 de "tesouro da bestice rural e urbana" (SCHWARZ, 1970, p. 70). Reproduz-se a lógica do ufanismo como "aberração".
}

o gosto das multidões frequentemente passam ao largo dos gostos de nossas elites culturais. Então cabe aprofundar o questionamento: quem hegemoniza o discurso acerca de nossa música popular? Se pensarmos no Brasil como um todo, esse contingente universitário adorador da MPB era muito diminuto. E mesmo nestes grupos, cabe repensar o foco de observação para além da "hegemonia" da resistência.

Uma longa tradição de intelectuais trabalhou com o referencial da resistência da "hegemonia cultural da esquerda", explicita ou implicitamente, focando seus interesses na oposição ao regime e seguindo os passos de Schwarz.

Todas essas canções demonstram que a distinção entre resistentes e "alienados" foi uma construção muito apurada no sentido de diferenciar os artistas do campo e tachá-los de "frutos da indústria cultural" pura e simplesmente. No entanto essa visão não dá conta das ambiguidades da realidade.

A distinção, embora respondesse a questões estéticas, era sobretudo fruto de partidarismos ideológicos, políticos e teóricos. Equivocada, porém bem disseminada, essa concepção fundamentou o discurso contra a música sertaneja. E dificultou compreender metamorfoses que tanto nossa música popular quanto nossa sociedade viveram em conjunto.

\section{Referências}

ALONSO, Gustavo. Simonal: quem não tem swing morre com a boca cheia de formiga. Rio de Janeiro: Record, 2011a.

. Bob Dylans do sertão: tropicália, MPB e música sertaneja. In: REDD - Revista Espaço de Diálogo e Desconexão. Araraquara, v. 3, n.2, jan.-jul., 2011b. p. 222-235.

. O sertão na televisão: música sertaneja e Rede Globo. In: Revista Contemporânea, Niterói, v. 1, n. 1, p. 222-235, 2011c.

Jeca Tatu e Jeca Total: a construção da oposição entre música caipira e música sertaneja na academia paulista (19541977). In: Contemporânea - Revista de Sociologia da UFSCar, São Carlos, v. 2, n. 2, p. 439-463, 2012a.

O sertão vai à faculdade: o sertanejo universitário e o Brasil dos anos 2000. In: Revista Perspectiva Histórica. Salvador, v.2, n.2, 2012b. p. 99-111.

. Ame-o ou ame-o: música popular e ufanismo durante a ditadura nos anos 70. In: Boletim Tempo Presente (UFRJ). v. 7, $2013 a$.

. O píer da resistência: contracultura, tropicália e memória no Rio de Janeiro. In: Achegas.net, v. 1, p. 44-71, 2013 b.

. Oposição no sertão: a construção da distinção entre música caipira e música sertaneja. In: Outros Tempos, São Luis, v. 10, n. 15 , p. $122-145,2013$ c. 
Os caipiras chiques: a relação da música rural e a MPB nos anos 80. In: Tempo da Ciência (Unioeste), Cascavel, v. 20, n. 39 , p. $113-140,2013 \mathrm{~d}$.

Cowboys do asfalto: música sertaneja e modernização brasileira. Rio de Janeiro: Civilização Brasileira, 2015.

ALEM, João Marcos. O caipira e o country: a nova ruralidade brasileira. Tese (Doutorado em Sociologia) - Universidade de São Paulo, São Paulo, 1996.

ARAÚJO, Paulo Cesar de. Eu não sou cachorro, não: música popular cafona e ditadura militar. Rio de Janeiro: Record, 2003.

BOURDIEU, Pierre. A ilusão biográfica. In: FERREIRA, M. M.; AMADO, J. (Coord.). Usos e abusos da história oral. Rio de Janeiro: Fundação Getulio Vargas, 1996.

CALDAS, Waldenyr. Acorde na aurora: música sertaneja e indústria cultural. São Paulo: Companhia Editora Nacional, 1977.

COUGO JUNIOR, Francisco Alcides. Canta meu povo: uma interpretação histórica sobre a produção musical de Teixeirinha (1959-1985). Dissertação (Mestrado em História) - Departamento de História, Instituto de Filosofia e Ciências Humanas, Universidade Federal do Rio Grande do Sul, Porto Alegre, 2010.

FICO, Carlos. Reinventando o otimismo: ditadura, propaganda e imaginário social no Brasil. Rio de Janeiro: Fundação Getulio Vargas, 1997.

GUIMARÃES, Juarez Rocha; PAULA, Delsy Gonçalves de; STARLING, Heloisa Maria Murgel (Org.). Sentimento de reforma agrária, sentimento de República. Belo Horizonte: Editora UFMG, 2006.

MARTINS, José de Souza. Música sertaneja: a dissimulação na linguagem dos humilhados. In: Capitalismo e tradicionalismo. São Paulo: Pioneira, 1975. p. 103-161.

MÉDICI, Emílio Garrastazu. A verdadeira paz. Brasília: Imprensa Nacional, 1970.

MOTTA, Rodrigo Patto Sá. As universidades e o regime militar. Rio de Janeiro: Zahar, 2014.

MOORE JR., Barrington. Injustiça: as bases sociais da obediência e da revolta. São Paulo: Brasiliense, 1987.

MOREIRA, José Roberto; COSTA, Luíz Flávio de Carvalho (Org.). Mundo rural e cultura. Rio de Janeiro: Mauad, 2002.

REIS FILHO, Daniel Aarão; RIDENTI, Marcelo; MOTTA, Rodrigo Patto Sá (Org.). O golpe e a ditadura militar: 40 anos depois (1964-2004). Bauru, SP: Edusc, 2004.

REIS FILHO, Daniel Aarão. Ditadura militar, esquerdas e sociedade. Rio de Janeiro: Jorge Zahar, 2000.

ROLLEMBERG, Denise. Esquecimento das memórias. In: MARTINS FILHO, J. R. (Org.). O golpe de 1964 e o regime militar: novas perspectivas. São Carlos: EdUFSCar, 2006.

SCHWARZ, Roberto. Remarques surlaculture et la politique au Brésil, 1964-1969. In: Les Temps Modernes, Paris, n. 288, jul. 1970.

STARLING, Heloísa. Canto do povo de um lugar. In: PAULA, Delsy Gonçalves de; STARLING, Heloisa Maria Murgel; GUIMARÃES, Juarez (Org.). Sentimento de Reforma Agrária, Sentimento de República. Belo Horizonte: Ed. UFMG, 2006. p. 302-345.

\section{Fontes}

\section{Artigos de revista ou colunas de jornal:}

O Globo, Rio de Janeiro, 25 abr. 1972.

Sem autor. "Ouro para o bem do Brasil - São Paulo repete 32", $O$ Cruzeiro, Rio de Janeiro, 13 jun. 1964, p. 64.

Sem autor. "A toada engajada", Veja, São Paulo, 17 ago. 1988, p. 116-117.4

Sem autor. "Teixeirinha quer eleições diretas", Folha da Tarde, São Paulo, 17 jan. 1984. Apud: COUGO JR., 2010, p. 139.

\section{Músicas citadas:}

"A bailarina" (Marciano/Darci Rossi/Sargento Oliveira), João Mineiro \& Marciano, LP Esta noite como lembrança, Copacabana, 1980.

"A coisa tá feia" (Tião Carreiro/Lourival dos Santos) Tião Carreiro \& Pardinho, LP No som da viola, Continental, 1983.

"A grande esperança" (Goiá/Francisco Lázaro), Chico Rey \& Paraná, LP Quem será seu outro amor?, Sertanejo/ Chantecler, 1987.

"A grande esperança" (Goiá/Francisco Lázaro), Mary Terezinha, LP Kilômetro 1, Musicolor/ Continental, 1987.

“Amigo lavrador" (Moacyr dos Santos e Jacozinho), LP Jacó \& Jacozinho 76, Continental.

"Anistia de amor" (Darci Rossi/Dalvan/Marciano), LP Anistia de amor, Sertanejo/Chantecler, 1983.

"Bendito seja o Mobral" (Tonico/Tinoco/José Caetano Erba), Tonico \& Tinoco, Cp., Continental, 1972.

"Boia-fria" (Moacyr dos Santos/Jacó), Jacó \& Jacozinho, LP Jacó \& Jacozinho, Continental, 1973.

"Brasil caboclo exportação" (Miltinho), LP Jacó \& Jacozinho, Continental, 1973

"Cavalo enxuto" (Moacyr dos Santos/Lourival dos Santos), Jacó \& Jacozinho, LP Novos sucessos, Continental, 1969.

"Diretas já" (Mary Terezinha/Ivan Trilha), Mary Terezinha, LP Kilômetro1, Musicolor/ Continental, 1987.

"É isto que o povo quer" (Lourival dos Santos/Tião Carreiro/ Carlos Compri), LP Tião Carreiro e Pardinho: A caminho do sol, Chantecler, 1973.

"Esperança do Brasil" (Nhô Crispim/Tonico), Tonico \& Tinoco, LP 20 anos, Continental, 1964.

"Esperança do Brasil" (Nhô Crispim/Tonico), Tonico \& Tinoco, LP A marca da ferradura, Continental, 1971.

"Espinheira" (Manoelito Nunes/Dalvan), Duduca \& Dalvan, LP Espinheira, 1984.

"Filho de pobre" (Moacyr dos Santos/Jacó), Jacó \& Jacozinho, LP Ninho de cobra, Continental, 1975

"Gente da minha terra" (Goiá/Almir/Pereirinha), Jacó \& Jacozinho, LP Jacó \& Jacozinho, Continental, 1973.

"Herói da pátria" (Dino Franco), Biá \& Dino Franco, LP O preço da ambição, Chantecler, 1973.

"Homem de cor" (Roceri/Barrerito/Paulo Roberto Aiello), Trio Parada Dura, LP Último adeus, Copacabana, 1981. 
"Ladrão de terra" (Teddy Vieira/Moacir dos Santos), Luisinho \& Limeira, Cp. 78 RPM, Odeon, 1958.

"Levanta patrão" (Lourival dos Santos/Tião Carreiro), Tião Carreiro \& Pardinho, Tião Carreiro e Pardinho: Duelo de amor, Chantecler, 1975.

"Longe do asfalto" (Moacyr dos Santos/Jacozinho), Jacó \& Jacozinho, LP Ninho de cobra, Continental, 1975.

"Mágoa de boiadeiro" (Nonô Basílio/Índio Vago), Pedro Bento, Zé da Estrada \& Celinho, LP Mágoas de boiadeiro, Beverly, 1971.

"Marcha do tri” (Tonico/Tinoco/Pedro Capeche), Tonico \& Tinoco, Cp., Continental, 1970.

"Massa falida" (Domiciano), Duduca \& Dalvan, LP Massa falida, Chantecler, 1986.

"Natal de um órfão" (Alvimar de Oliveira/Creone/Barrerito), Trio Parada Dura, LP Mineiro não perde trem, Copacabana, 1974.

"Ninguém quis dormir" (Darci Rossi/Chitãozinho), Chitãozinho \& Xororó, LP Sessenta dias apaixonado, Copacabana, 1979.

"Novo rumo" (Dalvan), Dalvan, LP Novo rumo, Alvorada/ Chantecler, 1986.

"O caipira que foi na Lua" (Martins Neto/Moreno), Moreno \& Moreninho, LP 20 anos, Continental, 1970.

"O dinheiro compra tudo" (Luis de Castro/Benedito Seviero), Chitãozinho \& Xororó, LP Chitãozinho \& Xororó, Copacabana, 1986.

"O doutor e a empregada" (Roniel/Augusto Alves Pinto), Trio Parada Dura, LP Barco de papel, Copacabana, 1984.

"Osso duro de roer" (Antônio Ventura Filho/Zé Paulo/Milton José), Tião Carreiro \& Pardinho, LP A majestade o "pagode", Continental, 1988.
"Ouro para o bem do Brasil" (Moreno e Moreninho) Moreno \& Moreninho, Cp. 78 RPM, Sertanejo, 1964.

"Papai Noel" (Teixeirinha), Teixeirinha, LP Última tropeada, Copacabana, 1968.

"Para não dizer que não falei de flores" (Geraldo Vandré), Duduca \& Dalvan, LP Espinheira, 1984.

"Pensão da rua Aurora" (Tony Damito/Sebastião Ferreira da Silva), Jacó \& Jacozinho, LP Jacó \& Jacozinho, Continental, 1972.

"Presidente Médici" (Teixeirinha), Teixeirinha, LP O internacional, Continental, 1973, LPS 22001.

"Quero terra" (Dalvan/José Sanches), Dalvan, LP Desencontros, 1988, Alvorada/Chantecler, 1988.

"Saudade de minha terra" (Belmonte/Goiá), Belmonte e Amaraí, LP Saudade de minha terra, Continental, 1967.

"Sesquicentenário" (Tonico/Tinoco), Tonico \& Tinoco, Cps. Continental, 1972, CS- 674

"Transamazônica" (Tapuã/Geraldo Aparecido Borges), LP Minha Terra, RCA, 1971.

"Trem da vida (Estação da Luz)" (Nino/Dalvan), Dalvan, LP Dalvan, Alvorada/Chantecler, 1987.

"Vida de operário" (Marumby/D. Hilário/Nhô Neco), LP Tonico \& Tinoco: 28 ANOS: Minha terra, minha gente, Continental, 1970.

Recebido: 09 de agosto de 2016 Aprovado: 11 de dezembro de 2016

\section{Autor/Author:}

Gustavo ALONSO gustavoalonsoferreira@gmail.com

- Professor adjunto do departamento de Comunicação da Universidade Federal de Pernambuco (UFPE). Historiador, mestre e doutor pela Universidade Federal Fluminense (UFF). Autor dos livros: Simonal: quem não tem swing morre com a boca cheia de formiga (Record, 2011) e Cowboys do asfalto: música sertaneja e modernização brasileira (Civilização Brasileira, 2015).

- Associate Professor of the Communications Department of the Universidade Federal de Pernambuco (UFPE). Historian, M.A. and PhD from the Universidade Federal Fluminense (UFF). Author of Simonal: quem não tem swing morre com a boca cheia de formiga (Record, 2011) and Cowboys do asfalto: música sertaneja e modernização brasileira (Civilização Brasileira, 2015). 